\title{
12
}

\section{The Art of Managing Worldviews in Kenya's International Technology Sector}

\section{Tim Weiss and Klaus Weber}

\section{Introduction}

We have all seen them, widely shared inspirational quotations that come in tweet length and deliver general wisdom to our glimmering screens about what it takes to be a successful technology entrepreneur. In fact, these tweets are everywhere, and for one reason or another, their messages are extremely powerful. Think of a tweet-sized quote from Jeff Bezos (founder of Amazon and Blue Origin and owner of The Washington Post): "I knew that if I failed I wouldn't regret that, but I knew the one thing I might regret is not trying."

The core element of his message is the deeply held belief that failure is an inevitable part of a technology entrepreneur's journey - and indeed that the entrepreneur should embrace rather than avoid the power of

T. Weiss $(\bowtie)$

Zeppelin University, Friedrichshafen, Germany

K. Weber

Northwestern University, Evanston, USA

(C) The Author(s) 2017

B. Ndemo, T. Weiss (eds.), Digital Kenya,

DOI 10.1057/978-1-137-57878-5_12 
failure. This positive attitude and the inherent glorification of failure has become a mantra that surfaces again and again in many similar quotes. While in theory, we might all agree with Bezos, the question is whether the mantra holds true in the everyday life of a technology entrepreneur in, say, Kenya? Put more bluntly, are you really willing to fail? Usually, the answer is a little more complex than a simple yes or no.

To judge from the opinions and convictions that linger in such tweets and similar statements you hear at conferences and on pitch nights, it seems as if there is a rule book, a recipe, that if followed will lead to success. If there were only a single recipe, success as an entrepreneur would indeed be easy. Reality is, however, a little messier. In Kenya's diverse and multicultural technology entrepreneurship sector, everyone is exposed to a multitude of these recipes for success. Here, domestic advice mingles with international mantras about what successful technology entrepreneurs ought to do. The problem arises once you try to put the recipes into action. When you add them all up, you discover that some recipes are contradictory, others are not easily applicable, and some just do not make sense.

Think about it: Are you really a true technology entrepreneur only if you want your digital solution to change the world? Or is it okay to make incremental improvements? Can you call yourself a serious technology entrepreneur only if you focus on a single venture? Or what about your next employee? Are you making the right decision if you hire a referral from a good friend-Or is it a grave mistake? Implied in these and many more unanswered questions is a quest for a formula that works - a holy grail for becoming a successful technology entrepreneur in Kenya.

We wanted to find out what this holy grail looks like, if it exists. We sifted through many different opinions, perspectives, and convictions in Kenya's international technology sector ${ }^{1}$ in order to do two things. First, zoom out and from a bird's-eye perspective, organize the diverse statements into understandable big-picture themes ${ }^{2}$ — best described as

\footnotetext{
${ }^{1}$ This chapter is based on an academic article. For more detailed information about our methodology, the underlying theory, and a closer look at our findings, see Weiss and Weber 2016.

${ }^{2}$ There are different ways to investigate how participants in Kenya experience technology entrepreneurship. De la Chaux and Okune, for example, in Chap. 9 of this book, take a participant-centric approach and sort entrepreneurs, innovation hub staff, and investors into groups in order to expose
} 
worldviews. Worldviews are deeper holistic systems of beliefs, norms, and values that motivate the variety of opinions, perspectives, and convictions that we see in Kenya's international technology sector.

We found a Kenyan worldview and an international worldview that each prescribed unique characteristics an entrepreneur ideally ought to have and the strategies he or she ideally ought to follow to become successful. ${ }^{3}$ Consider, for example, the question of whether technology entrepreneurs should or should not pursue side hustles. The Kenyan worldview favors multiple ventures under management at the same time as the right approach, best embodied in the idiom "A true hustler chases the buzz!" In contrast, the international worldview takes a fundamentally different position and favors one venture under management at a time as the ideal route to entrepreneurial success, meaning that business opportunities should be pursued serially. Such conflicting worldviews in a community pose problems for the entrepreneur in managing expectations, aligning aspirations, and taking into account the demands and requirements of those who subscribe to the opposite worldview. Just like the two poles of a magnet, opposing and conflicting worldviews can cause confusion about what is right or wrong, and hence create tensions, as seen, for example, when an entrepreneur negotiates with an investor.

Given the diversity of the sector, what is the "right way to do it in Kenya" today? The question motivated us to zoom back in and try to understand those involved in Kenya's Silicon Savannah in order to find out how they deal with differing worldviews in their everyday work life. ${ }^{4}$

divergent views about the groups' prescriptions for overcoming barriers to flourishing technology entrepreneurship. In Chap. 10, similarly, Marchant proposes that nonprofit and for-profit values influence participants' actions in Kenya even though they are commonly perceived as incompatible, arguing that drawing on both logics can in fact be a great resource for technology enterprises. In the current chapter, we follow a similar line of thought, though with a different analytical approach.

${ }^{3}$ Note that the beliefs, norms, and values of each worldviews are idealized features of becoming a technology entrepreneur.

${ }^{4}$ Our argument is based on two insights. First, seeing worldviews as a cultural toolkit moves us away from seeing culture as a constraining force heading in one direction and allows us to see it as a resource and toolkit from which community member can select various elements to act (Swidler 1986). Second, cognitive psychology has developed the concept of mindsets, which brings to the fore the various ways that individuals collect and processes information and develop knowledge structures that are essential for navigating through reality (Walsh 1995; DiMaggio 1997; Eggers and Kaplan 2013). Taken together, these insights allow us now to explore how individuals deal with 
Imagine a conversation between an entrepreneur who adheres to the Kenyan worldview and a venture capital fund manager who adheres to the international worldview. They will enter the conversation with particular mindsets_-guides to using information and action (Walsh 1995) _ about how to deal with the worldview of their counterpart.

Does the venture capital fund manager know that the entrepreneur runs a car wash and a consultancy on the side? Is the entrepreneur prepared to tell the fund manager about all of his or her side hustles? If the fund manager and entrepreneur both adhere to their worldviews (the "Defender" mindset [see below]), we can imagine a scenario full of misunderstandings and frustration. However, with another mindset at work, the fund manager and entrepreneur can use the worldviews openly to come up with a solution that works for both sides (the "Blender" mindset [see below]). During our work, we found six mindsets that offer different approaches for navigating such tricky situations. In the following pages, we will sketch out, first, the five layers of each worldviews and then describe the six mindsets in detail. The art of managing worldviews leads to new, at-first-sight counterintuitive solutions that can help in finding a unique and collective Kenyan recipe for successful technology entrepreneurship.

\section{Zooming Out: Two Conflicting Worldviews in Kenya's Tech Community}

We conducted 156 interviews $^{5}$ in Kenya's international technology sector, all with the aim of holistically understanding the Kenyan and international worldviews. ${ }^{6}$ Worldviews are deep cultural structures that

and make use of culture, manifested here in worldviews. Different mindsets emerge with which community members manage the conflicting worldviews.

${ }^{5}$ The interviews were done in 2013 and 2014 with technology entrepreneurs (49 Kenyan, 10 Kenyan repatriates, and 22 expatriates), investors ( 2 Kenyan, 1 Kenyan repatriate, and 23 repatriates) and industry representatives (17 Kenyan, 4 Kenyan repatriates, and 28 expatriates).

${ }^{6}$ Our research used a grounded theory approach (Charmaz 2011; Suddaby 2006; Glaser and Strauss 2012), understood Kenya's international technology sector as a case study, and applied techniques of inductive theorizing and semiotics (Chandler 2007; Barley 1983). We used 
undergird, in this case, business activity with systems of beliefs, norms, and values related to the shoulds, should nots, rights, and wrongs of becoming and being a successful technology entrepreneur. ${ }^{7}$ They provide an in-itself coherent and encompassing view of the world that lays out which behavior is ideal, desirable, or undesirable (Koltko-Rivera 2004). A worldview matters! That is why, like a compass, a worldview holds out an often unreachable reference point_-an ideal_-against which to benchmark and align one's entrepreneurial mentality, strategy, relationship management, firm evaluation practices, and image of the self. ${ }^{8}$ In our study, all of these five layers of technology entrepreneurship were significantly affected by worldviews.

The presence of two different worldviews is comparable to using two different navigation instruments at the same time-say, a compass and a map. If you can read only one of the two but need to use both, then your entrepreneurial journey has just become seriously more complicated. Confusion can be immense, and the likelihood of getting lost is real. However, if both instruments are properly understood, they can, together, lend real clarity and direction. Similarly, a profound comprehension of the worldviews held by other people in Kenya's international technology sector has the potential to serve as part of a powerful personal formula for entrepreneurs navigating the domestic and global tech scene.

\section{Entrepreneurial Mentality: Hustling versus Single-mindedness}

In general, two distinct entrepreneurial mentalities are at play. In the Kenyan worldview, the distinct hustling mentality is a ubiquitous behavioral pattern

\footnotetext{
MAXQDA software (VERBI Software, Berlin, Germany) to code the final dataset of 77 interviews. The set was selected based on the richness, quality, and clarity of the interview materials.

${ }^{7}$ Note that the beliefs, norms, and values in both worldviews presented here are not prescriptions about what those involved in Kenya's international technology sector should believe but rather a representation of what they believe to be an ideal state.

${ }^{8}$ This is not an exhaustive or fixed list but rather a reflection of the dominant components that interviewees were talking about-meaning there might be components that could be added. We encourage our readers to engage in a debate with us in an effort to further revise and refine the worldviews.
} 
that cuts across income levels, religions, ethnic lines, and industry sectors. ${ }^{9}$ In its ideal form, it is best described as a proactive and outcome-focused mentality that seeks to generate income through finding fixes for many different problems or business opportunities. Think of an askari (Swahili for "guard") who is involved in far more than guarding a building. Picture an office employee who also has a chicken farm and, as a side hustle, runs a car wash and a consultancy. Or think of an entrepreneur who grows more than three businesses simultaneously. In the Kenyan worldview, this mentality is the norm rather than an exception. In the international worldview, by contrast, a different dynamic is at play. The technology entrepreneur, also known as techpreneur, has established a unique approach toward doing business. Think of Bill Gates, Mark Zuckerberg, or Jack Ma-working in a professional community of co-entrepreneurs. Their actions and successes are compared against each other's rather than those of real estate moguls, for example, or tycoons in the construction business. Indeed, professional techpreneurs champion a particular mentality. They make single-mindedness a discipline and are known for having a focused and experience-oriented mentality moving along a path toward self-fulfillment that seeks to develop a business solution for a single, fundamental problem.

The conflict between an outcome-focused mentality that seeks to generate income versus an experience-oriented mentality on a path toward selffulfillment stands out. The hustling mentality in the Kenyan worldview is deeply rooted in Kenya's history and an art brought to perfection in dealing with market and government inefficiencies. Arguably, without the hustling mindset, many day-to-day problems in Kenya would not find a fix, and many business opportunities would remain without that special someone who makes use of it. Although grounded in an entrepreneurial nature, hustling is in essence a means to pay the bills that are waiting at home. Put differently, in the mind of the hustler, entrepreneurship is a job more than anything else. The focus is on getting the job done. In the international worldview, a different belief reigns. Ideally, techpreneurs are not only involved in growing a business, they are also thought to be on a

\footnotetext{
${ }^{9}$ For more details, see Chap. 13 Eskor John and conversation \#13 with Mikul Shah and Ritesh Doshi, in this book.
} 
personal mission. They are expected to be enmeshed in a profound personal process toward self-fulfillment and realization. Entrepreneurship is meant to be far more than just making ends meet, it is a deeply personal journey to find one's true calling and what one was meant to do in life. Embarking on this journey is therefore not supposed to be solely driven by a need for money but rather by a passion for creating value for customers and society.

Taken together, these worldviews reveal fundamental differences in the purposes of entrepreneurship. In one view, entrepreneurship is mostly a pragmatic approach to make ends meet, and in the other view, entrepreneurship is supposed to be part of a broader, personal exploration. This can cause misunderstandings and tensions. Through the lens of the hustling mentality, it seems irrational and foolish to focus on only a single problem. What if the problem becomes irrelevant? How do you generate income and create wealth? Through the lens of the singlemindedness mentality, it seems untrustworthy to be always ready for the next job. Are you serious in anything you do? And will you ever be successful?

\section{Entrepreneurial Strategies: "Hedge Your Bets" versus "Exploit One Niche"}

The entrepreneurial mentality is inextricably linked to the entrepreneur's interaction with the market and larger environment. The hedge-your-bets strategy seeks to exploit multiple business opportunities in unrelated industry sectors at the same time. This diversification strategy makes business creation in multiple industry sectors a well-respected and recognized business norm in Kenya. To an outsider, the accumulation of businesses may follow no particular rationale. In the Kenyan worldview, however, the strategy is a logical next step in, for example, seizing the abundant opportunities Kenya has to offer and it is one of the necessary evils hidden in starting businesses in general. For entrepreneurs who adhere to this worldview, a look abroad is a welcome and comfortable source of inspiration and usually helps to identify business opportunities 
and solutions that do not seem apparent at first glance in Kenya. This leads to the importation of foreign business solutions to tackle market inefficiencies (see Chap. 4 by Marissa Drouillard). However, each imported solution also comes with a perception fallacy. Although a business may thrive and flourish in another market, it can easily suffer from significant downsides once put to work in Kenya. The reason for this is that the fundamental assumptions built into the business model can turn into flaws ${ }^{10}$ if not addressed. A business clone must be carefully examined and assumptions need to be questioned to develop adequate adaptations for those that prove flawed in Kenya. A prominent topic, for example, is functional integration. Often times, the creation of a new business is accompanied by the need to establish peripheral businesses in order to successfully realize the primary business' aim. Here is why: Think of an e-booking site that first has to push hotels into the digital age (i.e., leading to the creation of a peripheral business such as a consultancy or a separate business entity for hotel software development and marketing) before turning to the primary business endeavor that sought to aggregate and offer hotel bookings on the World Wide Web. If there is no one who does it for you, then an additional business is needed to solve these peripheral problems, pushing entrepreneurs into seizing multiple business opportunities in parallel.

Quite the opposite holds true in the exploit-one-niche strategy, which seeks to seize a single business opportunity in a market niche, one opportunity at a time. Ideally, the techpreneur meets multiple opportunities sequentially, addressing a new business opportunity only after an earlier opportunity has been fully exploited. To an outsider, this international worldview may seem odd. But it is based on the strongly held conviction that in order to be successful an entrepreneur should identify and pursue only one market niche and contract out peripheral business problems to third parties. The rationale for this is that a focus on one particular market niche allows the techpreneur to holistically comprehend the market, develop specialized expertise and experience, craft an adequate solution to the underlying problem,

\footnotetext{
${ }^{10} \mathrm{See} \quad$ www.livemint.com/Companies/9MS2eZjmYwcC040ktsu5JP/The-fault-in-our-startups. $\mathrm{html}$ for an extensive discussion of clone flaws in India's start-up scene.
} 
and develop strategic capabilities so that a copycat can't drive the techpreneur's venture out of business. The fundamentals of the exploitone-niche strategy are clear: The techpreneur is supposed to create a specialized enterprise, and peripheral problems are supposed to be contracted out to other businesses, allowing strategic partnerships to rise. This functional integration creates the notion of a well-connected business landscape whose elements rise and fall together.

In sum, the Kenyan worldview promotes the simultaneous creation of multiple enterprises in order to generate substantial income and build up wealth in a complex environment. Expectations built on this worldview regard people who do not seize the many opportunities as careless and suggest to those who propose the contracting out of peripheral problems as a little far removed from reality. In contrast, the international worldview offers a blueprint for a highly specialized enterprise that focuses on developing core competencies in order to realize a comparative advantage and pave the way for an exponential growth trajectory in a highly competitive environment. Viewing the world through this lens causes community members to wonder how a competitive edge or market dominance can ever be realized by spreading yourself thin, because doing everything yourself seems like you are not doing it right!

\section{Relationship Management: Relations versus Contracts}

How do you hire employees you trust? How do you select partners you want to team up with? And how do you ensure they deliver? The Kenyan worldview has a clear answer, in which trust in one's contacts and loyalty stand on an informal network-driven approach to business. Business collaborations that matter are therefore not merely a function of aligned business interests for mutual gain; in their ideal form, they rather reflect an outcome of longstanding and deeply trusted relationships with family, friends, and colleagues that reach back to joint secondary school or university attendance. Social is first, business comes second! Business relationships are embedded in a social network and need to be cultivated and protected. Not only "who you know" matters (i.e., status and reputation) but also "how well you know someone" (i.e., quality). An entrepreneur 
who, for example, hires a referral from a trusted network contact over someone who is more adequately trained for the job is following the preferred reliance on social safeguards-favors and obligations ensure that the referral delivers on the agreed goals. This may mean that the startup's performance is overall lower than if a fully qualified person were on the job. But the referrals and recommendations from trusted sources ensure the start-up's functionality and protect the employer from adverse employee behavior.

In the international worldview, incentive schemes and contracts stand on trust in formal business relationships. Ideally, a business relationship becomes trusted and sealed with a formalized contract. Contract violations are seen as a breach of trust. As a consequence, the hiring of employees circles around aligning interests between the start-up's goals and the employees' capabilities. Here, the start-up's goals and objectives are of primary importance. They come first and are, in general, the main driver behind forming business relationships. Detailed incentive plans, performance-based salaries, or equity-based compensation plans are seen as well-suited instruments to ensure alignment and performance of employees. If needed, judicial measures protect the company from adverse employee behavior.

Both worldviews rely on different arrangements. In the Kenyan worldview, the entrepreneur is part of a social network who-depending on the quantity, quality, and status of her or his contacts - may be able to unlock important resources and thereby help ensure the continuing performance and success of the start-up. Proponents of this view perceive the excessive use of formal contracts as a killer of the dynamic nature of business, primarily because it is not practical to try to pack all eventualities into a contract. In the international worldview, the primacy of company objectives coupled with the reliance on contracts creates a dynamic in which compliance with detailed contracts and individualized incentive schemes matter for start-up performance and success. This perspective sees informal business arrangements as highly suspicious, opaque, and secretive, suggesting involvement in nepotistic business activities. A cooperative or investment deal with community members who bank on informal relationships is highly unlikely for someone who believes in the primacy and power of contracts. 


\section{Firm Evaluation: "Bricks and Mortar" versus "Strategic Value"}

A company's evaluation is probably one of the most contested issues during an entrepreneurial journey. It not only determines the cost of capital and informs contractual negotiations, it also sets the stage for the future relationship between the entrepreneur and financiers. In short, there is a lot that can go wrong.

In the Kenyan worldview, company evaluations are based on assets and revenue, and investors use brick-and-mortar businesses as a reference to assess the potential of new investment options. Imagine a technology venture that developed a digital solution and a committed investor offered a take-it-or-leave-it deal for a huge slice of equity—say, USD100,000 for $85 \%$ of equity. This seems like a high equity price, yet it is indeed a realistic valuation. Why? The Kenyan worldview provides an answernamely, that real estate, land, and property development represent a secure, desired, and representative investment destination, with more or less guaranteed returns. These investments are low-risk and offer moderate returns, pushing investors to focus exclusively on tangible brick-andmortar businesses. They form the dominant reference category against which any other investment is judged, compared, and evaluated. Put differently, technology businesses are in competition with brick-and-mortar deals, where evaluations are based on business fundamentals such as market share, assets, profit margin, existing revenue, and projected revenue. In addition, the absence of realistic exit routes ${ }^{11}$ underlines the belief that a conservative investment and entrepreneurial philosophy, in which a business should grow based on generated revenue, paves the way to success.

In stark contrast lies the international worldview, in which evaluations are based on growth potential, strategic value, and investors assess and compare the value of new investments in technology enterprises with those of ventures that have the same or similar characteristics. Ideally, high-risk technology enterprises should mingle in a dedicated investment category. This allows investors and entrepreneurs to use industry-specific measures

\footnotetext{
${ }^{11}$ See Chap. 14: Venture Capital in East Africa: Is There a Right Model? by Stephen Gugu and Wilfred Mworia.
} 
to evaluate and compare high-risk companies with each other. Traction, unique user visits, and the conversion rate are just a few among the many metrics that are specifically designed to grasp the business realities and future potential of technology ventures. In an environment where earlystage ventures offer little information, highly specialized investors pick up the latest industry trends, and their investments serve as proxies for perceived entrepreneurial success and future performance. These investments are normally publicly reported and believed to be an essential steppingstone to building a recognized and successful company. A vibrant exit market where buyouts and initial public offerings represent viable avenues for liquidating investments enables creative pricing strategies that determine potential market or strategic value. This affects business strategy in turn and allows a start-up to rely on investors' fuel to keep the engine running. In an equity-financed growth trajectory, revenue generation is secondary.

Taken together, the Kenyan worldview on firm evaluations is deeply anchored in brick-and-mortar businesses and favors a conservative investment philosophy. Through this lens, an investment deal of USD100,000 for $85 \%$ of equity in a technology venture that owns a few laptops and generates almost no revenue is a reasonable and good offer. Anything else would be irrational, if not lunatic, and completely out of context. In the international worldview, high-risk technology ventures are a legitimate asset class and represent the norm rather than an exception. Through this lens, an early-stage investment deal of USD100,000 for $85 \%$ of equity is irresponsible and toxic and can only be met with sarcasm in order to retain what little sanity is left! Technology entrepreneurs who hold the international worldview are therefore unlikely to find an investor among those who hold the Kenyan worldview.

\section{Self-Image: "Catching up" versus "Leading the Way"}

Self-image answers the question of how we view ourselves, our sector, and our country in relation to other countries on the globe. For example, in times of uncertainty and of many unknowns, where do you turn for advice and solutions? Do you seek outside help or rely on your own capabilities? 
The self-image inherent in the Kenyan worldview is a mark of a complex and deeper-lying historical cause. ${ }^{12}$ In its contemporary nature in Kenya's technology sector, it is best captured by an outward looking logic in which advice and solutions from abroad are largely seen in a positive light. These are believed to be the adequate source of inspiration and learning. In particular, foreign business ideas and management philosophies are introduced and adopted with high authority. Caused by a constant comparison and benchmarking with nations that are regarded as "advanced," a sense of "catching up with the rest of the world" lingers in this worldview and provides a source of inspiration, motivation, and at the same time, frustration. ${ }^{13}$ The role of foreign aid, for example, attracts continuing attention because grant capital and donor-driven projects are a ubiquitous remedy used to try to address economic, social, political, and cultural problems. Not only is foreign aid prevalent in the nongovernmentorganization landscape and political sector, but it also mingles in the private sector, creating multiple approaches to doing business (see Marchant, Chap. 10). Despite all this, foreign commitment to Kenya is eyed critically ${ }^{14}$ and characterized as hesitant, ambiguous, and largely provisional.

The international worldview offers a strong contrast, in which the belief dominates that advice and solutions from within are superior and that internal capabilities produce state-of-the-art solutions. "The solution lies within you!" Solutions developed within a start-up, community, or nation are inherently superior and cutting-edge. They will set new standards and lead the way toward progress, change, and development. This inward perspective creates a view of the world that others will inevitably start making reference and comparison to in order to learn from

\footnotetext{
${ }^{12}$ For a thorough understanding of the historical causes, the current global economic order that reproduces them, and the dynamics of colonialism and post-colonialism, turn to the many famous philosophers who have analyzed the African condition in rich detail. To name just a few: Asante 2015; Fanon 2005; Mazrui and Wondji 1993; Mazrui 1974; Mbembe 2003; Mudimbe 1988; Ndlovu-Gatsheni 2010; Thiong'o 2009.

${ }^{13}$ See in this book, conversation \#1 with Jimmy Gitonga.

${ }^{14}$ See in this book, conversation \#3 with Anne Shongwe.
} 
and imitate. It is entrepreneurship and business activity that take a key role in addressing today's problems, be they societal ills, environmental hazards, or market inefficiencies.

In a nutshell, because of profound historical developments, those that adhere to the Kenyan worldview in technology entrepreneurship favor foreign solutions. In fact, foreign solutions are largely perceived as superior. From this angle, local solutions are disregarded from the start as inferior, considered to have a high likelihood of failure, or seen as being merely a recombination of already existing solutions-reflected in a "We've been here before" attitude. ${ }^{15}$ The international worldview takes an opposite stance with a strong inward perspective in which solutions from within are superior. Through this lens, adapting foreign ideas and copying business models puts into question the true innovation potential of the Kenyan technology sector and its seriousness about disruption, change, and exponential growth.

\section{Zooming In: Mindsets Getting to Work}

These two worldviews have provided a bird's-eye perspective on the beliefs, norms, and values in their ideal form that mingle in Kenya's international technology sector. Arguably, the reality is not as stylized and nicely separated. Rather, the two conflicting worldviews blend in a diverse and international community. This leads to substantial problems in expectation management if members base their expectations, visions, understandings, and aspirations on opposite worldviews. The dynamic will lead to profound misunderstandings and frustration. However, there is a way out! Once the worldviews are fully understood, they provide rich information - a resource-that members of Kenya's tech community can use to build their start-ups (Swidler 1986; DiMaggio 1997). The

\footnotetext{
${ }^{15}$ See also prominent Kenyans critiques that go against this grain and are in favor of local solutions. Among them are Thiong'o 2009, Mwalimu Ali Mazrui's BBC radio Reith Lectures at www.bbc. co.uk/programmes/p00gq1wn for a phenomenal start into his way of thinking about the African condition and James Shikwati's critical reflections on "donor economics" at http://tinyurl.com/ Stop-aid-it-is-killing-Africa and http://www.nytimes.com/2006/11/18/us/politics/18thinktank. html? pagewanted=all\&_r=0
} 
challenge is to adequately put this knowledge to work. We zoom into the minds of Kenyas tech community members to showcase how to deal with and make use of the two different worldviews.

A mindset is an individually held point of view that lays out how the world works and helps in dealing with the complexity reality has to offer. It drives how we collect, analyze, and interpret information from the environment and is a product of past experience (Walsh 1995). Think of a filter. In principle, our mindset filters information and puts it in a particular frame so it can be interpreted. In day-to-day situations, our mindset comes in handy and guides us in understanding a situation and responding to it (see Eggers and Kaplan 2013 for a comprehensive overview). However, a narrow mindset can also limit us to familiar ways of thinking and acting (Dhanaraj and Khanna 2011; Hill and Levenhagen 1995). Ambiguous, uncertain, or entirely new situations challenge our mindset and require a shift or change to achieve a desired outcome. The more subconscious, hidden, and taken for granted a filter, the more difficult it is to create awareness and create change and versatility. In other words, if we cannot change our mindset, we will remain stuck in old behavioral patterns, repeat mistakes, and continue on the already beaten path without making use of the full potential a different perspective can offer. Ignoring the diverse resources that Kenya's international technology sector has to offer may well turn out to be a costly mistake.

Each dimension of the worldviews showed us the tensions and problems that those involved in Kenya's international technology sector face. Now we can move on to see which mindset is best equipped to deal with and make use of the worldviews. While reading through the following pages, it is best to ask yourself when you apply which mindset and whether it gives you the desired result. If not, you might want to consider developing another one.

\section{Mindset \#1: The Defender}

"I do it my way or no way!" describes a community member who adheres to one worldview only and insists on its principles with 
astonishing persistence. You will realize that you are logged into a Defender mindset if you face difficulties in understanding the rationale of your counterpart and keep insisting that your way is the only way. You will consider behaviors that bank on the other worldview as inferior.

Think of an entrepreneur in Kenya who criticizes and labels any advice from someone whose self-image is best characterized by "leading the way" as cocky accompanied by the expression "they don't understand the fundamentals of our market." Or think of an investor who is confronted with a hustling entrepreneur. By adhering to the single-minded techpreneur ideal, the investor will attribute a lack of seriousness and focus to the hustler, coming to the conclusion that, if the hustler does not quit his or her side hustles, an investment will be impossible. What the Defender does not see is that this mindset misses out on opportunities to learn profoundly from the market and work with rather than against the diversity of Kenya's international technology sector. The mindset may work in the short run, but in long run, the Defender will run into problems because new partners to work with will be hard to come by.

\section{Mindset \#2: The Pretender}

A champion in signaling, the Pretender has a vague, superficial understanding of the opposite worldview. All in all, the Pretender follows the worldview that is closest to the heart, paying only lip service to the opposite view. For example, a deep understanding of the meaning behind labels and metrics matters. Using CEO, UX, KPI, disruptive growth, and market trends too loosely or starting a clone with tags like "This is the Ebay of Kenya" would not help an entrepreneur in building credibility or unlocking new resources if the underlying meaning of these labels is only vaguely known or if the metrics cannot survive a thorough check. ${ }^{16}$ Instead, it creates false expectations, and the Pretender will run into the

\footnotetext{
${ }^{16}$ See Mbwana Alliy's post at http://savannah.vc/2012/12/19/10-deadly-mistakes-and-pitfalls-african-startups-should-avoid-in-2013
} 
perception trap-signaling proficiency and commitment when a closer look reveals ignorance.

Similarly, it is by now evident that networks drive business in Kenya. Relationships are "social first and business second." Paying lip service to the social-first component would not create trust. A blog post best illustrates this mindset. Malaika Judd (2013), a former investment manager at Savannah Fund, outlined prominent expatriate failures in East Africa. Among them, having no long-term plan for East Africa, having no Kenyan co-founders, staying inside the expat bubble, and not learning Kiswahili are behaviors that raise questions about the intentions of a Pretender. An investor should double check before sealing a deal.

The Pretender fails to understand the underlying meaning of the opposite worldview and thus lacks the authenticity and deep knowledge needed to build important connections that can facilitate access to finance, high-quality employees, and other business contacts necessary to run a successful business sustainably.

\section{Mindset \#3: The Pleaser}

The Pleaser integrates both worldviews at the same time- - but at a cost. In attempting to harmonize both of them in one start-up, she or he can then become occupied with pleasing multiple audiences. The Pleaser's focal task becomes managing stakeholder expectations in order to draw on a larger resource pool. This runs the risk of unraveling into a schizophrenic identity with two entrepreneurial mentalities.

An example of a pleaser can be a founder who draws on both grant and equity capital. Nested in the self-image, the Kenyan worldview understands foreign aid as a source to tackle grand challenges and finance market activities, and the international worldview regards business approaches as the superior solution to societal ills. Now, a Pleaser will combine both and simultaneously write grant proposals and compile pitch decks — selling the same idea with two different stories to two different audiences. The tension between both worldviews is thus imported into the start-up, most likely leading to a for-profit and non-for-profit 
entity, also known as a hybrid social business. ${ }^{17}$ Although it creates access to both worldviews, it also engenders a double management burden on individuals — multiple board meetings a year, numerous update reports, reapplication for funds, and harmonizing grant-capital-provider interests with those of equity financiers. This can be a viable strategy, but it is best reserved for those with high cultural competence, an extensive management skill set, and a gift for speaking with multiple audiences.

\section{The Art of Managing Worldviews}

Understanding worldviews alone is not enough. A personal openness is also needed to challenge the status quo, look for viable alternatives, and get community members enmeshed in a dialogue in order to replace old thinking patterns with new ones (Dhanaraj and Khanna 2011). Pushing beyond the status quo requires a deeper understanding of the rationales baked into each worldview-a form of cultural competence that reads the similarities, differences, and compatibilities in order to craft something "new" that will both be of collective value to Kenya's international technology sector and benefit the venture.

We have found three mindsets that do exactly that. They incubate novelties that have the potential, if widely adopted, to push Kenya's tech space to the next level - a unique Kenyan form of technology entrepreneurship that works and leads to high-level exits that benefit all. Admittedly, these mindsets do not come without downsides. Hence, they are not for everyone. But they are of central importance in attempting to develop Kenya's tech scene further.

\section{Mindset \#4: The Blender}

Combining the best of both worldviews into something new is the analytical focus of the Blender. Arguably, novelty emerges amidst experimentation and exploration. Let us look back at grant and equity financing. Although

\footnotetext{
${ }^{17}$ See also fascinating research on this topic by Battilana et al. 2012, Battilana and Lee 2014, and Battilana and Dorado 2010.
} 
the integration of both instruments at the same time causes coordination challenges, a sequenced approach may well be the way ahead-that is, start with grant funding where it makes sense and then test and mature your prototype, well knowing that grant capital would not last. The goal is not to become the "donors' darling," it is rather to create a product within the confines of the foreign aid logic with the ultimate goal of acquiring intensive market knowledge, increasing the company's valuation and, once the pilot has been tested, approaching debt or equity investors to get to market. The entrepreneurial strategy would be to first test and experiment using grants and then to embark on a growth trajectory using equity capital.

Another example is skillful translation, also known as "Africanizing it." This expression gets at the combination of the foreign and local. Rather than attributing absolute superiority to either foreign concepts or the local context, it makes sense to see truth in both of them and acquire competence in skillful translation. This holds true for any community member. Question the consequences of your behavior, such as, What are the implications if I strictly do not invest in a hustler? Yes, you remain true to your principles; however "Africanize your principles!" would mean to step out of your current mindset and think of a middle ground where an investor or mentor helps entrepreneurs find their way while growing a company. Investors and mentors should get obsessed about finding out new ways how that can be done rather than drawing up contracts to best ensure that the hustler does not launch into something new on the way.

Similarly, rather than idealizing and glorifying what the technology gurus from abroad have to say, it makes sense to put on a lens that africanizes their advice. Why does failure matter so much to Jeff Bezos? What does failure mean for an entrepreneur in Kenya? Obviously, for many in Kenya, putting all their eggs in one basket comes close to suicide, but opening up to the possibility of failure detaches you from your business idea, frees you from overly conservative business approaches, and allows you to accept defeat if something does not work out. "Failcons" or "Fuck-up Nights," 18 emanating from Mexico, are innovations that came from such a mindset.

\footnotetext{
${ }^{18}$ This movement is about sharing business failures publicly, serving to demystify failure, and enhancing its general acceptance. For more information, see http://fuckupnights.com/
} 
As familiar practices are left behind, new patterns emerge. They are inherently unstable and may lead to a new practice that actually worksor to one that fails. The mindset comes with a caveat. Potential downsides are nested in the absence of the familiar, the instability of the new, and an overly strong focus on the novel that can divert your attention away from the operational business.

\section{Mindset \#5: The Educator}

The Educator, also known as the friendly guru, possesses the gift of deeply comprehending both worldviews, intuitively reading individuals, and seeing the worldview others adhere to. He or she is in a unique position to create awareness for both sides, lifting those stuck in their narrow mindset out of their own boundaries. Without the Educator, there would be no reflection on what is happening or, more importantly why it is happening. The Educator introduces reason and structure into what is happening and connects history with the present in order to show options for the future.

During our research, we were fortunate enough to meet a handful of these community members who have become role models in Kenya's international technology sector. It is impossible to draw up a conclusive list that does justice to all of them, but this short list combines tremendous wisdom with a strong sense of community that Ken Njoroge, Mike Macharia, Joseph Mucheru, Isis Nyong'o, Carey Eaton, ${ }^{19}$ Jimmy Gitonga, Ory Okolloh, Erik Hersman, Juliana Rotich, and Bitange Ndemo all share in common.

Pitfalls of this mindset are that you become a highly visible go-to person, meaning you will get enmeshed in highly political and contested issues, will have to play multiple roles, and may easily get sidetracked into a political agenda that would not allow you to fully focus on business.

\footnotetext{
${ }^{19}$ Carey Eaton was cherished as a genius with his heart at the right place. He died recently in a tragic incident. See www.whiteafrican.com/2014/06/06/remembering-the-genius-and-grace-ofcarey-eaton/ for more information.
} 


\section{Mindset \# 6: The Innovator}

Taking unresolvable differences and creating innovative solutions characterizes the Innovator mindset. The Innovator looks for the counterintuitive. Rigid boundaries and huge areas of tension and contestation in the community become particularly good grounds for novel solution development. We will outline three such solution strategies that deal with contested issues in Kenya's tech community-hustling, adequate financing, and cultural differences. Some have already been launched and put into action; others are mere inspirations.

\section{Financing the Hustler}

Hustling versus single-minded entrepreneurship has received mostly informal attention. Lingering underneath the surface of discussions and reports, it seems as if the front lines are clearly demarcated without much movement. An ideal ground for a new solution! While one side believes that side hustles are a necessity to grow a tech enterprise in Kenya, the other side strongly advocates for a focus on only one venture. It seems as if an "either-or" approach is the only solution. Yet there is another way. A possible solution for incubators, accelerators, and investors can be to deliberately select parallel entrepreneurs, as they are known, that have the most businesses in their portfolio. After all, championing the "hedge your bets" strategy suggests a well-connected, seasoned, and diversified entrepreneur with at least three different businesses along with a deep knowledge of Kenyan business trends and dynamics. The task of the incubator, accelerator, and investor is then to assess, analyze, and work through all the side businesses with the entrepreneur in an effort to create synergies, introduce new strategy concepts, and work on a venture together.

This solution focuses on two aspects-on the one hand, respecting the entrepreneurial reality and accommodating the entrepreneur in an open collaboration in which disclosing all the side-business activity is positively valued. On the other hand, the solution seeks to grow both the entrepreneur and a focal business. Taking parallel entrepreneurship as a given rather than an abnormality demands entirely new strategies for working with the entrepreneur that are aimed at streamlining business activities. As one of our interviewees said, "There is a time and place for hustling. You got to know when you have to let go." 


\section{Combining the Chama and the Venture Capitalist}

The chama and the venture capitalist are well-established and highly sophisticated institutions. Both were created to deal with financial assets, though in diametrically opposite ways. The chama is primarily a local, bottom-up social vehicle and selects its members based on social networks. In a chama, collective saving or investing in personal or low-risk assets among family, friends, or colleagues is in the foreground. Venture capital funds are primarily a nonlocal, top-down economic vehicle-a financial intermediary - that channels capital from diverse and geographically dispersed investors into high-risk businesses. Infusing the lean, voluntary, and trusted management structure of a chama with the spirit of a venture-capitalist-style economic vehicle would direct the chama's investment targets toward high-risk businesses.

This solution does two things. On the one hand, it draws on the social network function that business relationships are built on and gathers medium- and high-net worth individuals into an investment group geared toward investing in Kenyan businesses outside of the regular investment targets. It leverages the networks, experience, and capital of the chama members in order to help verify and grow new businesses. On the other hand, it shifts the focus of the chama to an economic function, using the joint capital pool to invest in high-potential and high-risk investments rather than making the safe bet. This solution provides a Kenyan alternative to the high cost structures current private equity and venture capital funds face in the East African market (see Chap. 14).

\section{On-Arrival Training for Newbies}

Imagine you are new to a country; you will most likely dive into the Net or buy a Lonely Planet in order gather some information about the new place you in - and you will be able to gather quite a lot of information. But you will miss some of the unwritten rules - the cultural nuances. This holds true for foreign techies coming to Kenya and for Kenyans venturing into the world of technology entrepreneurship. In each case, the language, norms, and the way you interact are new. For a foreigner, being fluent in Kiswahili, knowing how to eat ugali skillfully, or knowing why East African Breweries dubbed a beer "Senator" matters. The same holds 
true for Kenyans. Not only is the language of techpreneurs with all its buzzwords completely different from that of other sectors, but also what is considered to be "hip" and "cool" differs. The devil is in the details! and admittedly, learning the details is difficult and time-consuming.

A training program for both Kenyans and foreigners, however, could facilitate a controlled exposure to the culture of one's counterpart-a unique opportunity to learn how the game is played. Not everyone picks up these peculiarities right from the start. Rather than going through a painstaking six-month period in which everyone only scratches the surface, this solution can be a unique opportunity to learn the meaning of and reasoning behind each others' behaviors and terms.

As always, there are also downsides to this mindset. The Innovator is met with opposition, resistance, and a small peer group to work with. Counterintuitive and inherently new solutions face an uphill battle until they become recognized and fully accepted. The bearers of this mindset will therefore find only few supporters who fully understand and support the solution. So being able to take a long breath when working through potential failures and to bear with comments such as "I told you it ain't worth it!" are assets.

\section{Concluding Remarks}

How do we move forward from here? In our opinion, the co-existence of two different worldviews in Kenya's international technology sectorthe Kenyan worldview and the international worldview-is a blessing. It opens up novel ways to practice technology entrepreneurship, ways that take domestic conditions seriously and see the future in a skillful blending of domestic and international wisdom-because narrowing the scope to only one worldview dramatically reduces access to the financial, human, and organizational resources locked behind the other worldview.

We do not subscribe to the idea that one worldview is superior to the other. Rather, we believe that the two worldviews together can be a great resource to help create a Kenyan understanding and definition of technology entrepreneurship that creates truly innovative products. All this comes with an important caveat. We are not pushing diversity at all cost; 
we are aware that it creates a new set of problems that require both community members who are willing to explore the art of managing worldviews and an audience that is ready to listen and try new approaches. Given the historical trajectory of Kenya's tech scene, we believe that this is the "hotbed of innovation" that will not only bring forth remarkable product innovations but can also infuse technology entrepreneurship with its unique Kenyanness.

\section{References}

Asante, M. K. (2015). African pyramids of knowledge. Brooklyn: Universal Write Publications LLC.

Barley, S. R. (1983). Semiotics and the study of occupational and organizational cultures. Administrative Science Quarterly, 28(3), 393-413.

Battilana, J., \& Dorado, S. (2010). Building sustainable hybrid organizations: The case of commercial microfinance organizations. Academy of Management Journal, 53(6), 1419-1440.

Battilana, J., \& Lee, M. (2014). Advancing research on hybrid organizing Insights from the study of social enterprises. The Academy of Management Annals, 8(1), 1-44.

Battilana, J., Lee, M., Walker, J. \& Dorsey, C. (2012). In search of the hybrid ideal. Stanford Social Innovation Review, Summer.

Chandler, D. (2007). Semiotics: The basics (2nd ed.). New York: Routledge.

Charmaz, K. (2011). Constructing grounded theory. London: Sabe Publications Ltd.. Dhanaraj, C., \& Khanna, T. (2011). Transforming mental models on emerging markets. Academy of Management Learning \& Education, 10(4), 684-701.

DiMaggio, P. (1997). Culture and cognition. Annual Review of Sociology, 23(1), 263-287. doi:10.1146/annurev.soc.23.1.263.

Eggers, J. P., \& Kaplan, S. (2013). Cognition and capabilities: A multi-level perspective. The Academy of Management Annals, 7(1), 295-340. doi:10.108 0/19416520.2013.769318.

Fanon, F. (2005). The wretched of the earth. New York: Grove Press.

Glaser, B. G., \& Strauss, A. L. (2012). The discovery of grounded theory: Strategies for qualitative research (7th ed.). New York: Transaction Publishers.

Hill, R., \& Levenhagen, M. (1995). Metaphors and mental models: Sensemaking and sensegiving in innovative and entrepreneurial activities. Journal of Management, 21(6), 1057-1074. 
Judd, M. (2013). Top 10 failures expat entrepreneurs make in East Africa. Savannah Fund - Waterhole Blog. http://savannah.vc/2013/12/16/top-10failures-expat-entrepreneurs-make-in-east-africa/\#.Vma2rmPTpBo. Accessed 19 Feb 2016.

Koltko-Rivera, M. E. (2004). The psychology of worldviews. Review of General Psychology, 8(1), 3-58.

Mazrui, A. A. (1974). World culture and the black experience. Seattle/London: University of Washington Press.

Mazrui, A. A., \& Wondji, C. (Eds.) (1993). UNESCO general history of Africa. Abridged Ed. Volume 8 Africa since 1935. Berkeley: James Currey and University of California Press.

Mbembe, A. (2003). Necropolitics. Public Culture, 15(120003), 11-40.

Mudimbe, V. Y. (1988). The invention of Africa: Gnosis, philosophy, and the order of knowledge. Bloomington/Indianapolis: Indiana University Press.

Ndlovu-Gatsheni, S. J. (2010). Do 'Africans' exist? Genealogies and paradoxes of African identities and the discourses of nativism and xenophobia. African Identities, 8, 281-295.

Suddaby, R. (2006). What grounded theory is not. Academy of Management Journal, 49(4), 633-642.

Swidler, A. (1986). Culture in action: Symbols and strategies. American Sociological Review, 51(2), 273-286.

Thiong'o, N. (2009). Something torn and new-An African renaissance. New York: BasicCivitas Books.

Walsh, J. P. (1995). Managerial and organizational cognition: Notes from a trip down memory lane. Organization Science, 6(3), 280-321.

Weiss, T., \& Weber, K. (2016). Globalization in action: Templates, tensions and strategies of action in Kenyan technology entrepreneurship. 


\title{
Conversation \#12
}

\author{
How to Be a Rebel and Build \\ a Business at the Same Time
}

\section{Ken Njoroge of Cellulant Corporation}

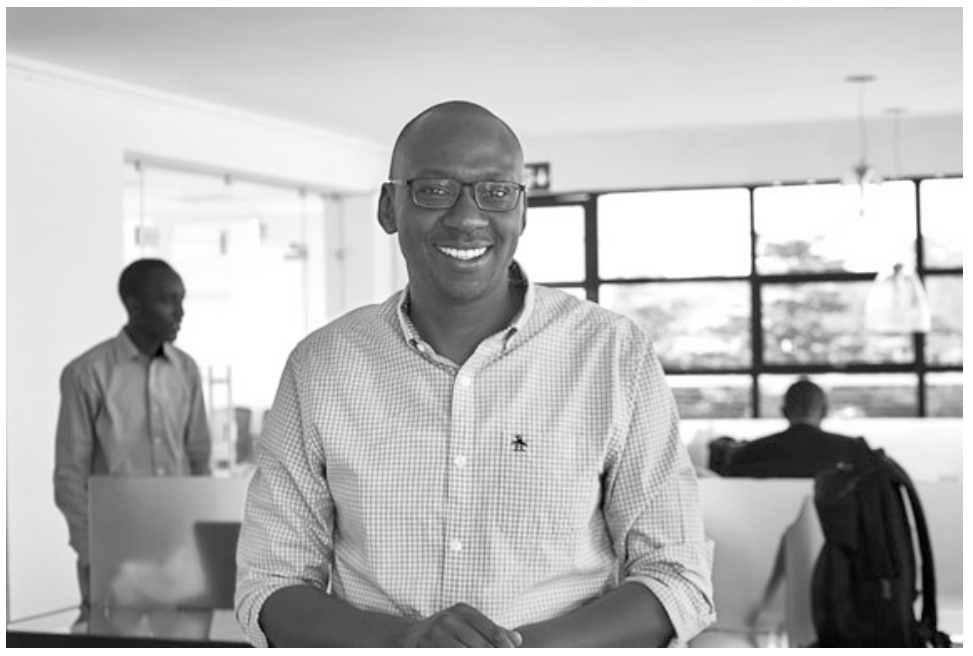

Ken Njoroge is the co-founder and group chief executive officer (CEO) of Cellulant, one of Africa's leading mobile commerce companies. He has led Cellulant from being a dream he and his co-founder Bolaji Akinboro sketched on a napkin in 2003 to an organization with a staff of more than 240 spread across 10 countries. Unwavering in his pursuit of excellence, Ken is dedicated to seeing Cellulant achieve its goal of connecting more than 100 million consumers with digital payment services that are relevant to their daily lives. 


\section{What is the story behind Cellulant?}

Cellulant is a payments business serving the mobile commerce market segment. Mobile commerce is a familiar segment to people who have heard about M-PESA, for example, and about mobile banking in Africa. However, we did not start out, 14 years ago, in mobile commerce. We started as a mobile content provider, selling music downloads over mobile phones. At the time, we knew there were going to be a big opportunities in mobile, but we did not know what shape or size they would come in.

After about three or four years of selling digital content, we noticed a couple of things. First, notably, that our early adopters were rural or near-urban and slightly older, in their early 30s and mid-30s. This was interesting - and very different from what we had expected. We had gone into the business thinking our customers would be urban, slightly younger, more tech savvy, and richer. Second, we noticed that when we offered music and ringtones on credit, so that customers could pay the one-dollar cost in three or four chunks, then our sales generally quadrupled. The basic thinking began to form around the fact that a lot of the services on mobile were really mass market, meaning that if you could build useful services they could reach large numbers of consumers and that if you could find a way to innovate on the payments model then you could actually charge fair value for services - a dollar for a ringtone, for example, even though the average top-up value at that time was just slightly over half a dollar.

This triggered a new thought process on the mission of the business. The goal was very clear since our founding: We wanted to build a billion-dollar enterprise. We set out on a plan that suggested we could get there if Cellulant had 100 million customers using our services and made USD1 per customer per month. By 2008, it had become clear that mobile payments and mobile money were going to be a big space, and we began to look actively at these as a potential future for us, thinking we could basically leverage the payment innovation we had developed for music and ringtones on credit into a mainstream payment system. 
In 2009, we became a business that was building a future on the back of mobile commerce. We ended up developing a couple of products for payments and banking and sold these to quite a large number of banks over time. This marked the second phase of our growth, in which went from being a music and ringtone business in Kenya to being a mobile commerce company in Kenya, Nigeria, Tanzania, Malawi, Uganda, Zambia, Ghana, Zimbabwe, Botswana, and Mozambique.

Today, we are a business that is running a shared payment ecosystem, powering services for about 71 banks, including some of the large multinationals across the region. We also serve other nonbank customers, including major utility companies and governments that are looking to provide services and get paid digitally over mobile phones or the Internet.

\section{You initially started out to study pharmacy at a university but discov- ered your passion for computers and the Internet along the way. Do you think it was the right decision to switch to computers?}

Yes, it is one of the best decisions I have made in my life-although I have to admit I got into computers almost purely by accident. Immediately after high school, I was admitted to a pharmacy school. I think it was quite an elite school in those days, admitting only about 25 students at a time. But there was going to be a two-year lag between high school and actually entering the university—and my mom, a single parent, just did not like the idea of me hanging around and doing nothing for two years! She came across a newspaper advertisement saying that one of the other universities, Strathmore (traditionally an accounting and business school), had started a computer program and was calling for students to apply for scholarships. So I applied, luckily got a scholarship, and went off to Strathmore for the time being.

I, of course, fell in love with computers extremely fast. But also I fell in love with the schooling and the teaching culture of the university, because we had lecturers who were practitioners in the industry. One in particular, who is today the CEO of Uchumi (one of Kenya's 
largest supermarket chains), would bring the Times and Newsweek magazine articles about Bill Gates and Steve Jobs and all the cool things they did in the early days of Silicon Valley.

As a result, I got socialized, not just on computers but also on entrepreneurs who were doing interesting things. The cutting-edge technology of the time and the entrepreneurs globally who were not much older than I was made a powerful impression on my mind. So when I went to the pharmacy school after the two years were up, I saw that my mind had started to develop in a completely different direction from that of the medical school culture. This was a very significant culture clash for me. I only lasted about a year and a half and came to the conclusion that this was not going to work. So I and went back to Strathmore for another year!

\section{You started working for several Internet service providers (ISPs), and in 1998, decided to make the transition and start 3Mice. Why was it the right time?}

By the time I left Strathmore, the desire to become an entrepreneurlike Steve Jobs, Bill Gates, and the Netscape founders- - had already settled in my mind to a point of no return. The basic direction, the highest level where one could go in terms of ambition as a technology person, had settled.

\section{What does it mean for you to be an entrepreneur?}

I think I am a rebel_-self-directed maybe, but a personality who likes to have his own mind about things. For me, it was never about the money, but rather about the fact that you could, almost from a blank sheet, create and build something, out of your own thoughts, and shape it into whatever it could become. That was a very powerful idea for me. It still continues to drive me today. It is just an innate personality trait. Then seeing other entrepreneurs and what their companies were doing gave this trait a shape and a form of expression. It is like an artist-except that an artist expresses himself or herself in, say, a painting. I figured that you could express rebellion, sort of your view of the world, in the ability to create something new and great-and that you can do that with a business as well. This desire was deeply ingrained in me by the time I left Strathmore. 


\section{When you say rebel, what do you mean? Rebelling against what?}

In our society, we were socialized to go to high school, get extremely good grades, go to university (and, in my case, go to the top course), excel in the university, and then be successful. Breaking away from that mold - coming to terms with the realization that "Hang on, this particular path that has been prescribed doesn't actually make sense for me and doesn't fit with my interests and passions"-was quite a clear departure from the norms of our society at the time.

Of course, my dropping out of the university was difficult for my mom, because it is not what people do. Saying, "Well, this doesn't make sense for me; I'm going to do something different" is a form of rebellion. And the way you then express it - and it was not rebellion for rebellion's sake-is a very specific reflection of why this was not going to work for me and why there ought to have been a much better, much more exciting path to pursue for my career.

\section{What were some of the main learnings you took with you from 3Mice?}

3Mice (a Web hosting and design company in Nairobi) was a fantastic learning opportunity because it was the first business I set up. The most important thing I took out of 3 Mice is that one can actually do these things and do them well. I think the fact that, from nothing, we set up a business that became reasonably well known in the country was a very powerful lesson. The other lesson unfolded when we became an Africa online company, witnessing a Pan-African business in the making very early on in my career and to see, again, that it can actually be done.

The other more practical lessons were on the "how-to" side, like how to get products to market and how to build teams. What really matters are people. 3Mice was a partnership of three people, and what got us all excited was creating a company very early on. However, it was a common motivation, a common vision, and a common purpose that kept the partnership alive as the business model changed and evolved. What innately drives entrepreneurs is essentially their purpose and vision- "How big do you want this to go?"- and they are important in keeping things 
together. I learned the value of having them aligned very early on and applied it to my future partnerships. So when I moved on to Cellulant, my co-founder Bolaji and I spent a lot of time making sure we were aligned on those things. To a large extent, our extremely successful partnership at Cellulant is a result of those early learnings.

\section{What was the effect of 3Mice on Kenya's tech-ecosystem?}

The 3Mice journey was a very short one when you look at how long it typically takes to have large impact. I certainly can say that a lot of today's big, more experienced industry people came from within or around 3Mice. Paul Kukubo, for example, who became $\mathrm{CEO}$ of the Kenya ICT Board, was one of the co-founders of 3Mice. We certainly created a strong foundation for the belief in technology and in start-ups. The spirit still lives on. And of course, I too have been a significant beneficiary of coming from 3Mice. It built a lot of my credibility. When I say that I was involved in 3Mice, everybody always lights up and says, "Oh, 3Mice!" They can see that, "Okay, this guy is a serial entrepreneur — and not a shabby one!"

\section{Would you consider yourself more of an "ideational" entrepreneur, the kind who launches an idea and, once it matures into a business, moves on to the next idea?}

I would say that to some extent this is true. I think I am an ideas guy. But then, I am a bit of a boring guy too. For instance, for 13 years, I have now been with Cellulant, and I have this relentless focus to achieve a mission. What is common to both my journey at $3 \mathrm{Mice}$ and at Cellulant was a relentless mission to build a business on the scale of the ventures in the early days of the Internet: the Netscapes, the Microsofts, the Apples.

So what I have done is change my role as the business grew. I am still with Cellulant. I am not going to leave Cellulant anytime soon, because I have an almost dogged commitment to building a business of scale and achieving the mission of making Cellulant a billiondollar enterprise. 
I enjoy building ideas. What happened was that instead of leaving Cellulant to go and start another company, I just changed my job within Cellulant. Recently, we got a new COO who takes away a lot of the dayto-day operational activities and makes sure that projects are delivered on time and that sort of thing. This gives me a lot of time with the product guys to create the new ideas of tomorrow, within Cellulant-a very interesting configuration for me. I do not see myself starting another business after Cellulant, but I do see a lot of job changes coming my way so that I continue to be an ideas man within Cellulant.

\section{In a nutshell, what would you say are some of the key fundamentals that make an entrepreneur successful?}

There are at least two ways to look at it.

There is what I call an innate, almost intangible driver that gives one the motivation to succeed. It has to be very deeply rooted in a person, because it basically serves as the fuel to pursue an original path and gives you the strength to push for success. In my case, it gave me an extraordinary drive to succeed. I come from a single-parent family, as you know, and we are always driven and drilled to succeed despite the odds. I also come from a continent that I believe requires this kind of mindset to lift itself and reach its potential. Another fundamental trait found in entrepreneurs is ambition and motivation. This has to come naturally for entrepreneurs to succeed. I consider myself generally ambitious and motivated. Otherwise, why aim for a USD1 billion Pan-African company?

You will also hear entrepreneurs described as focused, resilient, and committed to a mission. These qualities translate into the business in various ways. So looking at focus, I once asked myself, "What do I know about real estate? And what do I know about all this other stuff?" Nothing, really! But in technology, because I have been at it for such a long time, I can develop very specific, deep insights that are scarce. And as a result of that, I can spend time creating opportunities and ideas because deep knowledge puts me in a reasonable position to succeed. That is why I have been in technology and a technology entrepreneur 
since September of 1998, when I co-founded 3Mice. I have followed the same path of building a technology business at scale ever since. I have been on that journey, I have not wavered, I have not given up. And even today, I do not allow myself to get into distractions that seek to take me away from the journey. So to me, that is focus! I am also resilient. It does not really matter how difficult a situation is-I wear it down! I always say I feel sorry for problems that come my way, because there is only one way it is going to end. I am going to wear the problem down! (Laughs.) The problem has no chance. I will look at it, I will turn it around, I will go home, I will sleep. Tomorrow, I will wake up and think about it and push it, and push it, and push it, until it breaks. (Laughs.)

\section{What was your biggest "Aha!" moment during your entrepreneurial journey?}

It must have been sometime in 2001 or so when I saw the pace at which mobile phones were growing. Before then, I used to look at the Internet in a PC mindset. I used to work in the ISP world, and we saw the Internet in sort of computer, PC, server ways. But when I saw the growth of mobile phones-I think, there were projections for Kenya for two million mobile phones by the year 2004, and Nigeria would have eight million—-now that was a big "Aha!" moment. It struck me like a thunderbolt, "Wow, this thing we call the Internet might actually make its way to the African mass market over the mobile phone." It was a real epiphany — an epiphany that started my journey with Cellulant.

\section{Thank you, Ken!}

\footnotetext{
(ब) (1) This chapter is distributed under the terms of the Creative Commons Attribution 4.0 International License (http://creativecommons.org/licenses/by/4.0/), which permits use, duplication, adaptation, distribution and reproduction in any medium or format, as long as you give appropriate credit to the original author(s) and the source, provide a link to the Creative Commons license and indicate if changes were made.

The images or other third party material in this chapter are included in the work's Creative Commons license, unless indicated otherwise in the credit line; if such material is not included in the work's Creative Commons license and the respective action is not permitted by statutory regulation, users will need to obtain permission from the license holder to duplicate, adapt or reproduce the material.
} 